
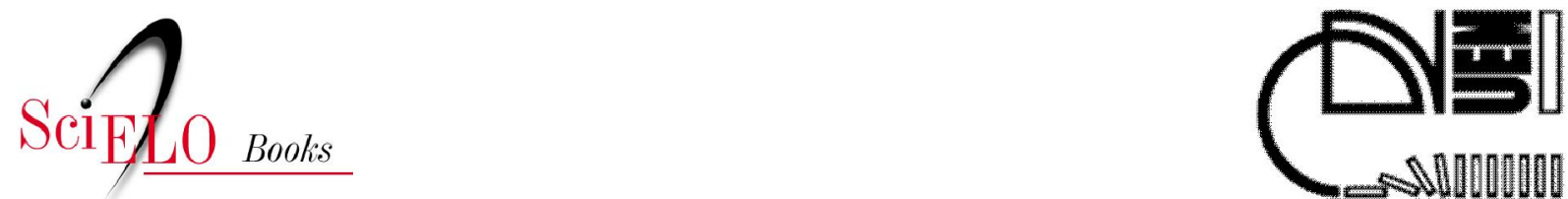

\title{
11 A revolta dos posseiros de 1957 no Sudoeste do Paraná
}

\author{
Angelo Priori \\ Luciana Regina Pomari \\ Silvia Maria Amâncio \\ Veronica Karina Ipólito
}

\section{SciELO Books / SciELO Livros / SciELO Libros}

PRIORI, A., et al. História do Paraná: séculos XIX e XX [online]. Maringá: Eduem, 2012. A revolta dos posseiros de 1957 no Sudoeste do Paraná. pp. 143-158. ISBN 978-85-7628-587-8. Available from SciELO Books $<$ http://books.scielo.org $>$.

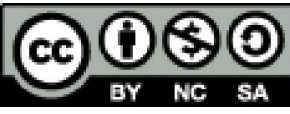

All the contents of this chapter, except where otherwise noted, is licensed under a Creative Commons Attribution-Non Commercial-ShareAlike 3.0 Unported.

Todo o conteúdo deste capítulo, exceto quando houver ressalva, é publicado sob a licença Creative Commons Atribuição Uso Não Comercial - Partilha nos Mesmos Termos 3.0 Não adaptada.

Todo el contenido de este capítulo, excepto donde se indique lo contrario, está bajo licencia de la licencia Creative Commons Reconocimento-NoComercial-CompartirIgual 3.0 Unported. 


\section{1}

\section{A revolta dos posseiros de 1957 no Sudoeste do Paraná}

Você já ouviu falar em luta pela posse da terra? Já parou para pensar que a luta pela terra surgiu muito antes do MST? Você, algum dia, já imaginou que o Estado do Paraná foi palco de diversos conflitos que envolveram a posse da terra? Você sabia que, até a década de 1940, grande parte das regiões Oeste e Sudoeste paranaense ainda não era efetivamente ocupada e que essa ocupação possibilitou o surgimento de conflitos armados? Se a maioria das respostas foi negativa, não se preocupe! Vamos esclarecer parte dessas indagações, discutindo a Revolta dos Posseiros do Sudoeste do Paraná e localizando-a no contexto dos conflitos pela posse de terra no Brasil.

De forma especial, as décadas de 1950 e 1960 foram marcadas por uma efervescente movimentação social no campo brasileiro: além das lutas pela posse da terra no Paraná (Porecatu e Sudoeste), Goiás (Formoso e Trombas) e Minas Gerais (Demônios do Catulé), ainda tivemos as Ligas Camponesas no Nordeste e a proliferação dos sindicatos dos trabalhadores rurais por todo o Brasil.

Pensar a questão da luta pela posse da terra requer que pensemos no intricado conflito de interesses que surge sobre terras devolutas oriundas da Lei de Terras de 1850: nesta data, foi promulgada a Lei $n^{\circ}$ 601, que 
"proibia a abertura de novas posses, estabelecendo que ficavam proibidas as aquisições de terras devolutas por outro título que não fosse a compra" (MARTINS,1983, p. 41-42). Em 1854, a regulamentação da lei permitiu aos que comprovassem cultura efetiva e moradia habitual a possibilidade de requisitar o seu quinhão. Nesse sentido, os territórios não reclamados foram considerados terras devolutas e, consequentemente, transformados em monopólio do Estado. No Paraná, a maioria das terras das regiões Oeste e Sudoeste encontravam-se nessa situação.

A Constituição republicana de 1891 transferiu a propriedade legal e o controle político das terras devolutas para os Estados. Essa mudança favoreceu a concessão de terras para companhias privadas e para o capital particular, circunstância que marcou o início da luta legal pela terra no Brasil. No processo de modernização econômica, desenvolvido nos primeiros anos da República, muitas terras devolutas foram utilizadas como forma de pagamento a empresas privadas, responsáveis pela construção de ferrovias. Foi exatamente isso que ocorreu no Sudoeste do Paraná. A titulação desenfreada do território, com suas consequentes disputas judiciais, fez com que as terras da região possuíssem vários 'donos': União, Estado, companhias particulares e o posseiro.

Como pagamento pela construção das estradas de ferro em território paranaense, o governo do Estado, logo no início do século XX, titulou, para a Companhia de Estradas de Ferro São Paulo - Rio Grande (CEFSPRG), subsidiária da Brazil Railway Company, as glebas Missões e parte da Chopim, ou seja, quase toda a região Sudoeste do estado.

Em 1930, estudando as concessões de terras realizadas no Paraná, Mario Tourinho, interventor do Estado no período, constatou irregularidades no cumprimento do contrato assinado com a CEFSPRG. Diante disso, anulou a concessão das glebas Missões e parte da Chopim. A Companhia não aceitou tal decisão e iniciou uma disputa jurídica para a manutenção da propriedade das terras no Sudoeste paranaense.

Porém, buscando salvaguardar os interesses da União, Getúlio Vargas, em 1940, incorporou todos os bens da Brazil Railway Company ao 
Patrimônio Nacional. Como a CEFSPRG era subsidiária dessa companhia, a pendência jurídica com o Estado do Paraná transferiu-se para o Governo Federal. Nesse sentido, Estado e União passaram a disputar o direito sobre as terras das glebas Missões e parte da Chopim.

Alheio a essa questão jurídica, dentro do contexto da 'Marcha para o Oeste', Vargas criou no Sudoeste paranaense, por meio do decreto n 12417 de 12 de maio de 1943, a Colônia Agrícola Nacional General Osório (CANGO), visando à ocupação e à consequente integração da região às demais regiões do Estado. A CANGO trouxe para o local milhares de posseiros que buscavam melhores condições de vida, oriundos, principalmente, do Rio Grande do Sul. Além destes, havia os posseiros que vinham independentemente e se instalavam nessas terras. Em nenhum dos casos, pela condição sub judice da região Sudoeste, eram fornecidos documentos de posse, circunstância que, alguns anos depois, tornaria incerta a situação dos posseiros no local.

No processo de valorização e expansão das fronteiras econômicas e demográficas, mais um 'proprietário' aparece no palco das disputas pelas terras do Sudoeste: a Clevelândia Industrial e Territorial Ltda (CITLA). Além dos posseiros e da questão subjudice entre Governo Federal e Estadual, a CITLA, em 1950, apareceu como a nova dona das terras constituídas pela gleba Missões e parte da Chopim.

A entrada da CITLA na comercialização das terras do Sudoeste foi cercada por opositores: a grande maioria dos trabalhos referentes à Revolta dos Posseiros de 1957 no Sudoeste do Paraná afirma que a transação que tornou a CITLA a dona das terras da região foi repleta de ilegalidade. Diante dessa afirmação, cabe ressaltar a forma como a CITLA iniciou sua participação nas negociações das terras do Sudoeste.

No início do século XX, um cidadão de nome José Rupp adquiriu do governo de Santa Catarina autorização para explorar ervais e matas no planalto catarinense. Essas terras seriam, a princípio, devolutas. Porém, em função da construção das estradas de ferro em solo catarinense, o mesmo território explorado por José Rupp foi cedido à CEFSPRG. 


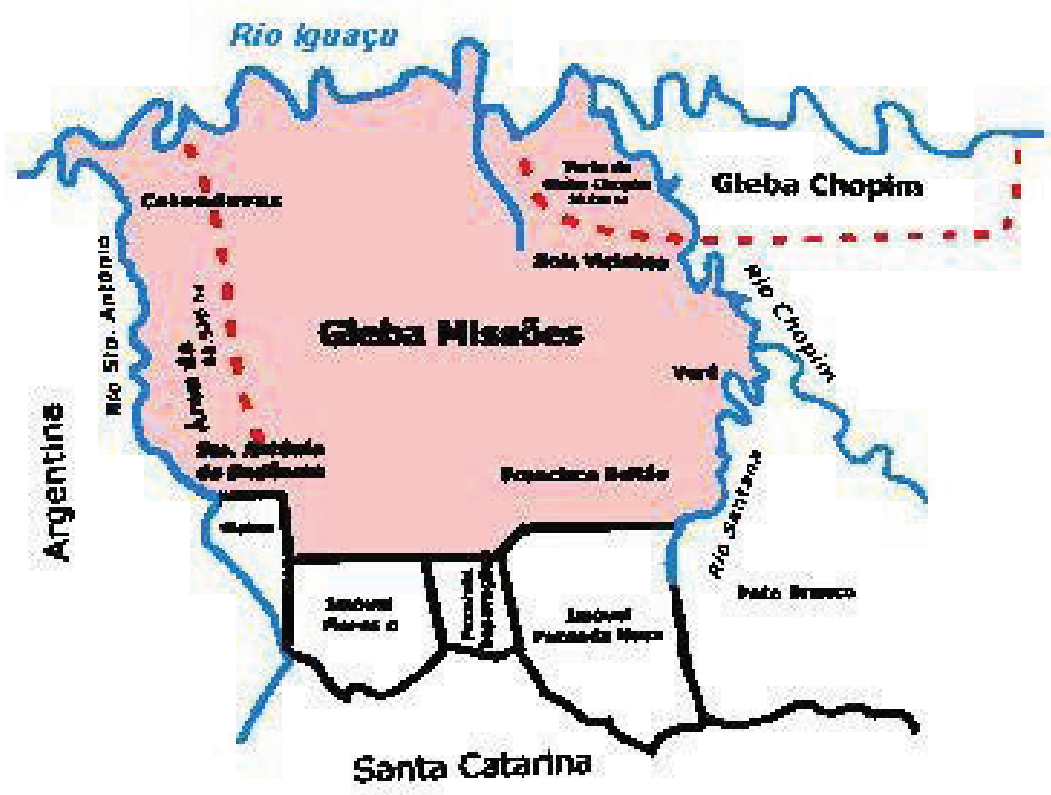

\section{Região de Atuação da CITLA}

Figura 1: Mapa da Gleba Missões Fonte: Krüger (2004, p. 215).

A fim de retirá-lo de suas concessões, a Companhia conseguiu, junto à Justiça, a manutenção da posse e a apreensão dos depósitos de erva-mate já extraída. José Rupp, inconformado com a decisão judicial, recorreu e, em 1925, teve parecer favorável: a Justiça reconheceu sua posse sobre as terras em litígio. Sem aceitar essa decisão, a CEFSPRG recorreu junto ao Supremo Tribunal Federal que, somente em 1938, confirmou a sentença a favor de José Rupp.

Foram 13 anos de disputas judiciais. Por entender, portanto, que esse período causou-lhes prejuízos econômicos, Rupp ajuizou, mais uma vez, uma ação ordinária de indenização contra a CEFSPRG pelos danos causados. Conforme Lazier (1986), em 1945 a Companhia foi condenada 
a pagar CR $\$ 4.720 .000,00$, mais juros de mora e custo calculados desde 1938, como indenização a José Rupp.

Como vimos acima, em 1940 o Presidente Getúlio Vargas incorporou os bens da CEFSPRG ao Patrimônio Nacional. Como essa Companhia foi condenada a pagar a indenização a José Rupp e seus bens, após o ato de Vargas, pertenciam ao Patrimônio Nacional, o pagamento pela indenização cabia, agora, ao Poder Público Federal. Frente a essa situação, de 1945 a 1950, José Rupp impetrou na justiça diversas propostas, inclusive a solicitação da gleba Missões como pagamento, sendo todas elas, porém, indeferidas.

Diante das negativas judiciais, Rupp cedeu seus créditos à Clevelândia Industrial e Territorial Ltda que, em poucos meses, conseguiu, junto à Superintendência das Empresas Incorporadas ao Patrimônio Nacional, a titulação das Glebas Missões e parte da Chopim. Portanto, algo que Rupp buscou por vários anos, a CITLA conseguiu em poucos meses: a transferência dos créditos foi feita em 26 de julho de 1950 e já em 17 de novembro do mesmo ano foi acertado o acordo sobre a indenização com a CITLA.

Essa rapidez na titulação das terras do Sudoeste é atribuída ao fato de Moysés Lupion, governador do Paraná pelo Partido Social Democrata (PSD), ser um dos sócios da CITLA, situação que teria facilitado a titulação do território à empresa. Assim, detendo praticamente todo o Sudoeste do Paraná, a Clevelândia Industrial e Territorial Ltda instalou-se na região em 1951, iniciando a venda de terras aos colonos ali instalados e gerando um clima de inquietação social entre os moradores.

Já em setembro de 1951 houve uma primeira reação à situação de intranquilidade gerada pela presença da empresa na região: colonos, comerciantes e profissionais liberais, em assembleia geral, constituíram uma comissão permanente para a defesa de seus direitos em relação ao litígio em torno das terras. Porém, essa forma de resistência mostrou-se ineficaz, pois não gerou nenhuma providência contrária à CITLA. 
A atuação dessa empresa estava intrinsecamente relacionada à ligação que ela mantinha com o governador do Estado. Quando as terras foram tituladas, quem estava no poder era Lupion, algo que facilitou a comercialização das terras pela CITLA.

Porém, entre 1951 e 1955 quem governou o estado foi Bento Munhoz da Rocha Neto, do PTB. A rivalidade política entre os dois partidos fez com que este governador se opusesse à CITLA, proibindo, "através do decreto n ${ }^{\circ}$ 419, de 02 de junho de 1952, o recolhimento dos Impostos de Transmissão e Propriedade, 'Sisas', de qualquer transação imobiliária nas glebas Missões e Chopim” (GOMES, 1987, p. 38). Assim, houve um interregno nas atividades da CITLA, que só voltou a atuar na região em 1955, após a re-eleição de Moysés Lupion.

Um dos primeiros atos do governador no seu novo mandato foi revogar a ordem que proibia o recolhimento das Sisas. Assim, em 1956, a CITLA, juntamente com duas outras companhias, Comercial e Apucarana, que se tornaram suas concessionárias, teve livre caminho para atuar no Sudoeste paranaense, iniciando as medições de vários lotes da região. Além disso, muita propaganda era realizada a fim de convencer os posseiros e colonos a dirigirem-se aos escritórios das companhias para assinarem os contratos de compra e venda das terras.

Frente à não aceitação dos colonos e posseiros ao fato de terem que assinar contratos e, também, à oposição ferrenha desempenhada pelos políticos da UDN e do PTB, contrários a Lupion, as companhias encontraram nos jagunços e na violência a melhor forma de alcançar seus objetivos. A indefinição jurídica que cercava as terras do Sudoeste paranaense possibilitou um ambiente de interesses conflituosos, em que a busca pelo lucro ultrapassava todas as formas legais de se resolver o problema da região: nem as autoridades policiais, nem as políticas mostravam-se interessadas na questão, o que impedia uma resolução pacífica do problema.

As primeiras reações contra essa violência foram realizadas por meio de abaixo-assinados pelos moradores da região. A ineficácia dessas 
ações diplomáticas mostrou-se, nitidamente, com a morte do Vereador Pedrinho Barbeiro, do PTB. Contrário às ações arbitrárias desenvolvidas pelas companhias CITLA, Apucarana e Comercial no Sudoeste, esse político organizou um abaixo-assinado que pessoalmente levaria ao Presidente da República, Juscelino Kubtschek, a fim de denunciar a realidade da região. Porém, antes da viagem para a capital federal, o vereador foi morto a tiros na própria residência, o que o impediu de levar adiante a reclamação contra as companhias.

Assim, em resposta a esse acontecimento, juntamente com o fato de não verem resultado pelas vias legais de resistência, os posseiros e colonos focalizaram nas armas a única solução para a situação:

Ao colono eram oferecidas duas alternativas: ou adquiria as terras sob o preço que lhe era imposto, ou deveria abandonar a terra. A atividade das empresas imobiliárias consistia em forçar a comercialização ou efetivar a 'limpeza da terra'. Foram sendo assim forjadas, progressivamente as condições de resistência do colono. Na luta contra a ameaça expropriadora de suas condições de trabalho, o camponês é levado à luta pela garantia da posse e pela legalização da propriedade da terra (REGO, 1985, p.208).

Dessa forma, em resposta a toda ação expropriadora das companhias de terra, somadas às frustradas buscas legais pela resolução do problema, os posseiros e colonos decidiram lutar à sua maneira. No lugar de ações pacíficas sem retorno prático foi instalado um processo de violência de ambos os lados. $O$ primeiro confronto entre jagunços e posseiros aconteceu em 2 de agosto de 1957, no distrito de Verê, quando um grupo de colonos armados marchou em direção ao escritório da Companhia Comercial. Na ocasião vinha à frente um colono envolvido em uma bandeira do Brasil que foi morto, ali mesmo, por jagunços.

Vários episódios que contêm estupros, covardias e violências físicas são narrados por quem se dedica ao estudo da Revolta dos Posseiros. Porém, o que mais marcou o conflito do Sudoeste foi a tocaia 
da camionete em 14 de setembro de 1957. Com o objetivo de acalmar os ânimos e fazer um acordo, o gerente da Companhia Apucarana, Gaspar Kraemer, marcou uma reunião com os colonos e posseiros em Lajeado Grande. Conforme Ruy Wachowicz (1985), a reunião foi cancelada, pelo fato de os dirigentes da companhia estarem desconfiados de alguma retaliação por parte dos revoltosos. Assim, ao invés de irem à reunião, mandaram apenas uma camionete com ordem para dar carona a quem estivesse na estrada. Tendo em vista o fato da realização da reunião, havia muitas pessoas pelo caminho. Sem saber da mudança de planos, um grupo de revoltosos atacou o veículo, matando sete pessoas. O que mais chocou foi que, das pessoas que morreram, apenas duas eram funcionárias da Companhia Apucarana.

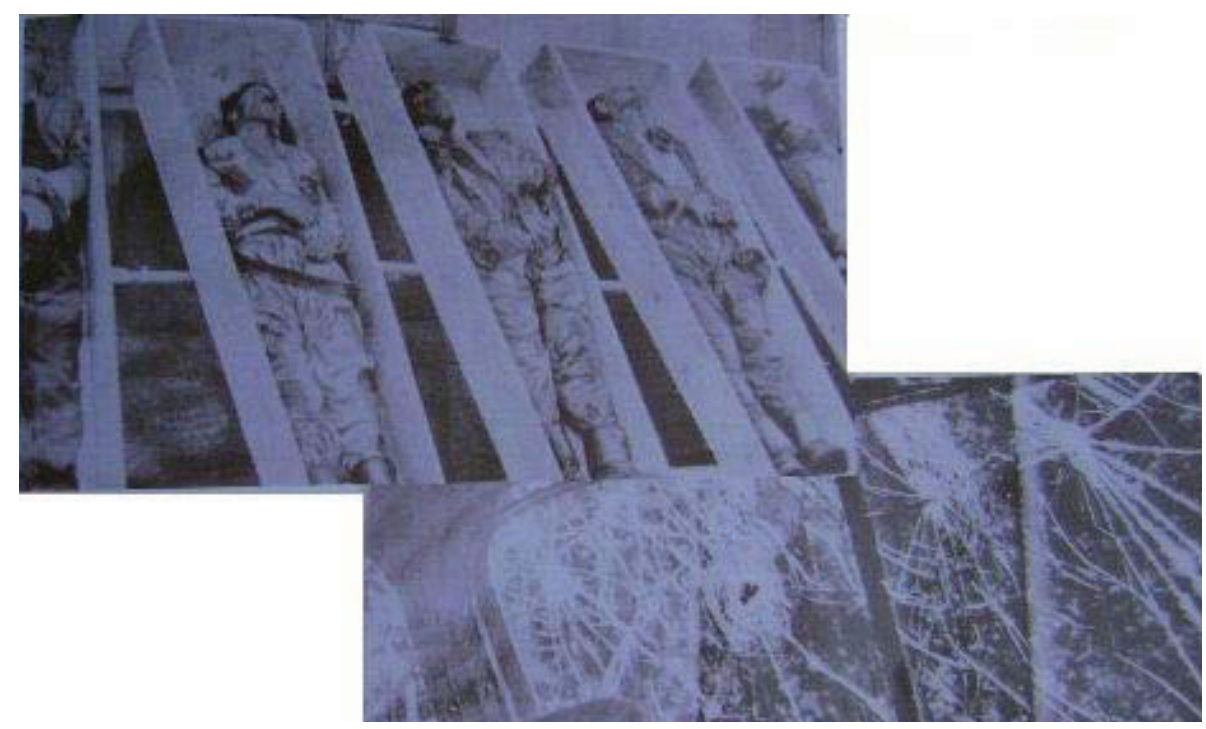

Figura 2: Episódio da camionete em 14/09/1957 Fonte: Paraná (2007, p. 13).

Indignados com a morte de companheiros, aproximadamente 2.000 colonos tomaram a cidade de Capanema. Os ânimos estavam exaltados. Alguma solução era necessária. Após o episódio do dia 14, a imprensa teve acesso aos acontecimentos do Sudoeste, fazendo com que os problemas 150 
da região alcançassem a opinião pública, por meio da veiculação diária dos acontecimentos por meio dos jornais. Conforme Iria Zanoni Gomes (1987), a polícia, em outras circunstâncias, poderia reprimir os posseiros e colonos e trazer novamente a paz para a região. Porém, tendo em vista essa repercussão na imprensa, juntamente ao fato de os revoltosos terem mostrado disposição à luta, isso fez com que Pinheiro Júnior, Chefe de Polícia, utilizasse métodos diplomáticos de persuasão para acalmá-los, a fim de impedir a ampliação do conflito. Tendo em vista que os colonos exigiam intervenção do Exército na região, Pinheiro Junior delegou o Coronel Alcebíades Rodrigues da Costa, conhecido pelos moradores, e o Tenentecoronel José Henrique Dias para fazerem o trabalho de desmobilização. Porém, a presença dos oficiais fez com que os jagunços se deslocassem para as áreas de Francisco Beltrão e Pato Branco, contribuindo para a intensificação da violência nessas regiões.

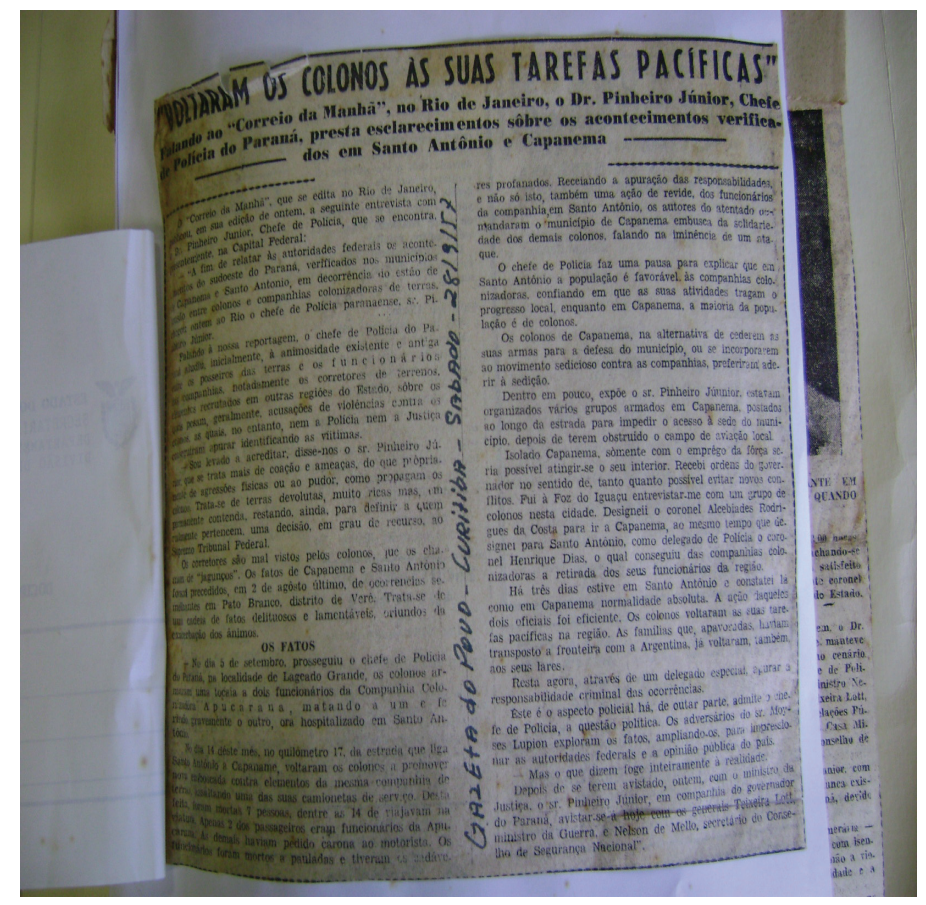

Figura 3. Noticiário sobre a Revolta de 1957 Fonte: DEAP (1957). 
A presença das companhias imobiliárias na região não perturbava apenas os colonos e posseiros, mas também os moradores das cidades, que se viam prejudicados pela paralisação das lavouras. Dessa forma, não somente os posseiros e colonos discutiam a situação, mas também os comerciantes e profissionais liberais passaram a posicionar-se contra as companhias. Além da evidente posição contrária dos políticos da UDN e do PTB, algumas lideranças urbanas também se destacaram na luta contra as empresas imobiliárias. Entre esses, podemos ressaltar Walter Pecóits (médico), Ivo Thomazoni (radialista), Edu Potiguara Publitz (advogado), Luiz Prollo (comerciante) e Jácomo Trento (mais conhecido como 'Porto Alegre, vendedor de equipamentos que percorria o interior do Sudoeste, adquirindo, com isso, mais informações sobre a situação da região). $\mathrm{O}$ diálogo entre campo e cidade foi, portanto, muito importante para a deflagração do movimento de 1957. Conforme Iria Zanoni Gomes (1987), bastava apenas um fato relevante para irrompê-lo.

Ruy Wachowicz (1985) afirma que o estopim se deu no dia 9 de outubro de 1957, quando três crianças foram açoitadas para revelarem o paradeiro dos pais que se encontravam refugiados por medo dos jagunços. Segundo Jácomo Trento $(2007$, p. 3), "as crianças estavam com vergões em todo o corpo, da grossura de um dedo". Após esse acontecimento,

\footnotetext{
o delegado da cidade, Alberto Geron, disse que não podia fazer nada, pois se o fizesse estava correndo risco de vida. Seus superiores haviam dado ordens para deixar as companhias trabalharem, sendo este, segundo eles, o interesse do governo. A população foi procurar então o juiz de direito, José Meger. Este, toda vez que havia requisitado forças para combater o banditismo, não recebia resposta e nem apoio (WACHOWICZ, 1985, p.197).
}

Sem apoio da polícia, os moradores sentiram necessidade de reação. Por meio da Rádio Colmeia, Ivo Thomazoni chamou o povo para uma reunião, em que discutiriam o problema das companhias. Conforme Iria Zanoni Gomes (1987), o número de participantes foi significativo. Uma das decisões foi a formação de uma comissão que iria até Curitiba 
e traria uma solução em três dias. Já na capital, tal comissão tomou conhecimento de que a Câmara dos Deputados havia aprovado a Emenda do Senado ao projeto do Legislativo que admitia o Ato do Tribunal de Contas e que negava o registro das glebas Missões e Chopim à CITLA, isso após seis anos transitando no Congresso Nacional. Outra decisão de que a comissão tomou conhecimento foi sobre o fechamento dos escritórios das companhias no Sudoeste, decretada por Moisés Lupion após a ameaça de uma intervenção federal na região. Porém, conforme Wachowicz (1985) e Gomes (1987), isso não foi suficiente para acalmar os ânimos da população.

Em Pato Branco, formou-se uma junta governativa provisória para as tomadas de decisões. A cidade foi ocupada por centenas de pessoas e foram montados piquetes para guarnecer as principais estradas de acesso a ela. O Major Machado esteve presente na região a fim de cumprir o fechamento dos escritórios da companhia. Conforme Iria Zanoni Gomes (1987), este usou a mesma estratégia do Coronel Alcebíades, designando Jácomo Trento, o Porto Alegre, conhecido pelos moradores, para auxiliálo na captura dos jagunços. A ação foi eficaz, pois muitas prisões foram realizadas, inclusive, e a mais importante, a do jagunço 'Maringá', autor das maiores atrocidades cometidas na região. Os que não foram presos se entregaram ou fugiram.

Em Francisco Beltrão, já no dia 10 de outubro de 1957, também foi formada uma comissão para tomada das decisões. Os colonos e posseiros foram chamados pelo rádio. A cidade foi ocupada por milhares de pessoas. Os jagunços foram presos antes de conseguirem fugir. Os revoltosos invadiram os escritórios das companhias, quebraram tudo, rasgando e jogando pela rua afora as promissórias e contratos que haviam assinado. Além disso, arrancaram a placa que dava nome à avenida principal e o obelisco comemorativo da fundação da cidade, por apresentarem o nome da CITLA.

Conforme Iria Zanoni Gomes (1987), essa reação teve um significado simbólico muito importante, pois, ao rasgar as promissórias e 
retirar da cidade os objetos que lembravam a empresa, posseiros, colonos e demais envolvidos no movimento demonstravam todo seu protesto e recusa a tudo que estivesse ligado às Companhias de terra.

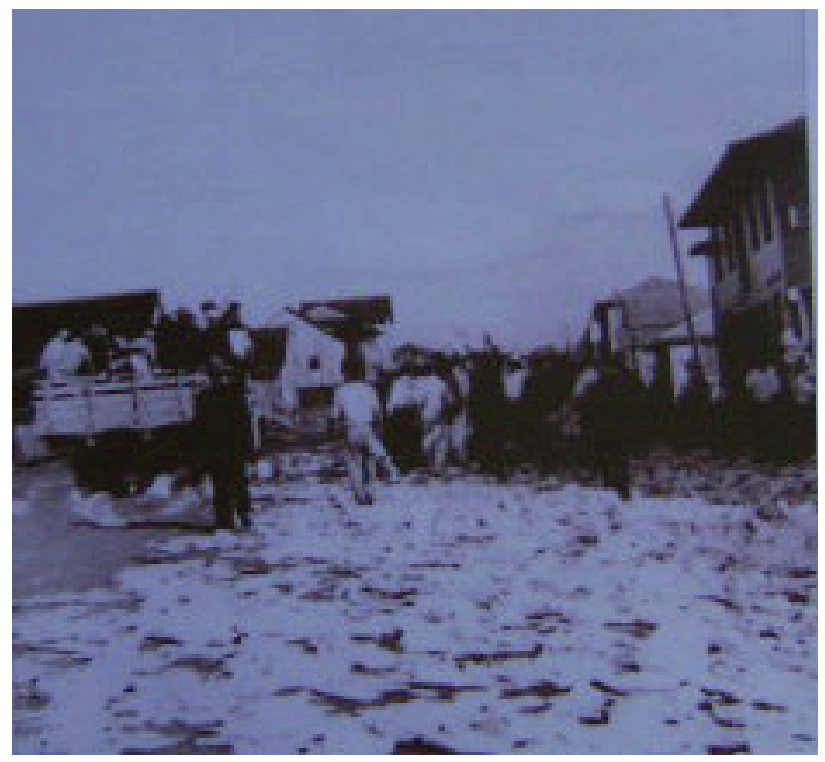

Figura 4: Rua de Francisco Beltrão forrada com os papéis destruídos pelos revoltosos Fonte: Paraná (2007, p. 09).

Os ânimos estavam tão acirrados que os revoltosos receberam à bala o Delegado da DOPS, enviado ao Sudoeste para investigar o ataque à camioneta no dia 14 de setembro. Diante da situação, Pinheiro Junior, chefe de polícia do Estado do Paraná, esteve pessoalmente presente no Sudoeste paranaense. Aceitando as imposições dos revoltosos, transformou o médico Walter Pecóits em delegado, prometeu a retirada completa das companhias e a demissão do promotor público e do juiz da comarca de Francisco Beltrão.

Em Curitiba, Moysés Lupion aceitou todas as condições impostas. De acordo com Iria Zanoni Gomes (1987), as ações de Pinheiro Júnior foram uma medida inteligente e necessária a fim de evitar um confronto 154 
maior que não era desejado pelo governo estadual por estar sob ameaça de intervenção federal pelos lutuosos acontecimentos decorridos na região.

Em Santo Antonio, assim como em Pato Branco, também foi formada uma comissão para a orientação do movimento. No dia 12 de outubro de 1957, exigindo um pronunciamento imediato sobre a questão de terras, os colonos tomaram a cidade. Cercaram a Delegacia, destituíram o delegado de polícia, prenderam um médico e um padre do distrito de Pranchita, por serem favoráveis à CITLA, invadiram e depredaram a casa do advogado de tal empresa, destruindo todos os contratos, documentos e promissórias que vinham sendo assinadas. E, mais uma vez, Pinheiro Junior concordou em atender às condições impostas pelos revoltosos para o restabelecimento da paz. Assim, evitavam-se a intervenção federal no Sudoeste paranaense e a consequente investigação do conflito, o que traria à tona o envolvimento do governador com as companhias de terras.

Após os ânimos terem se acalmado, foram enviadas até o Sudoeste tropas da polícia militar para a retomada do controle da região. Como essa atitude contrariava os acordos estabelecidos com o Chefe de Polícia, houve a possibilidade de um ressurgimento do conflito, pela indignação dos colonos. Porém, segundo Iria Zanoni Gomes (1987), isso não aconteceu. A polícia reassumiu as delegacias da região e, aos poucos, foi adquirindo a confiança da população. Resolvia-se, portanto, pelo viés policial, parte dos problemas da região: o fim da ação das companhias.

O conflito em si não foi muito extenso temporalmente, concentrando-se apenas no mês de outubro de 1957. Contudo, podemos dizer que foi resultado das experiências coletivamente vividas pelos posseiros do Sudoeste que, diante dos abusos sofridos, uniram-se para lutar contra o inimigo comum: as companhias de terra. Quando esse inimigo comum deixou de existir, ou seja, quando os escritórios das empresas colonizadoras foram fechados e seus documentos destruídos, a luta tornou-se dispensável. 
Porém, para que os frutos da revolta pudessem ser realmente colhidos, o processo de uma concreta definição jurídica para as terras do Sudoeste precisou ser tramitado no campo político (AMANCIO, 2009). As aspirações dos posseiros, manifestadas por meio da luta armada em 1957, precisavam ser tratadas na Câmara e no Senado para que surtissem efeitos legais para a sociedade sudoestiana. Assim, podemos dizer que a divulgação encontrada pelo conflito nos meios de comunicação social, somadas à sua apropriação pelos políticos oposicionistas a Moysés Lupion, foram fatores importantes para que a questão litigiosa das terras do Sudoeste fosse debatida no campo da política. Nos anos de 1958 e 1959, as terras da região foram declaradas de utilidade pública e de interesse social para fins de desapropriação e, em 1962, por meio da criação do Grupo Executivo para as Terras do Sudoeste (GETSOP), foram lançadas as bases para a efetiva regularização dessas terras:

Art. $1^{\circ}$ Fica instituído o Grupo Executivo Para as Terras do Sudoeste do Paraná (GETSOP), com a finalidade de programar e executar os trabalhos necessários à efetivação dos objetivos determinados no Dec. 50.494 de 25 de abril de 1961, para a desapropriação e, em convênio com o Estado do Paraná, planejar e executar a colonização das glebas desapropriadas ${ }^{16}$.

Assim, por meio da atuação da GETSOP, órgão responsável pela demarcação e divisão dos lotes das terras do Sudoeste paranaense entre os posseiros da região, a Revolta de 1957 alcançou seu triunfo: o fim da indefinição jurídica por tantos anos, vivida entre os colonos e posseiros sudoestianos. Por essa característica peculiar, o Sudoeste do Paraná é considerado uma das poucas regiões onde as pequenas propriedades são encontradas em maior concentração. Nesse sentido, podemos afirmar que a Revolta dos Posseiros foi um conflito vitorioso.

16 Decreto no 51.431, de 19 de março de 1962, assinado pelo Presidente João Goulart, que criou o 'Grupo Executivo para as Terras do Sudoeste' (BRASIL, 2012). 


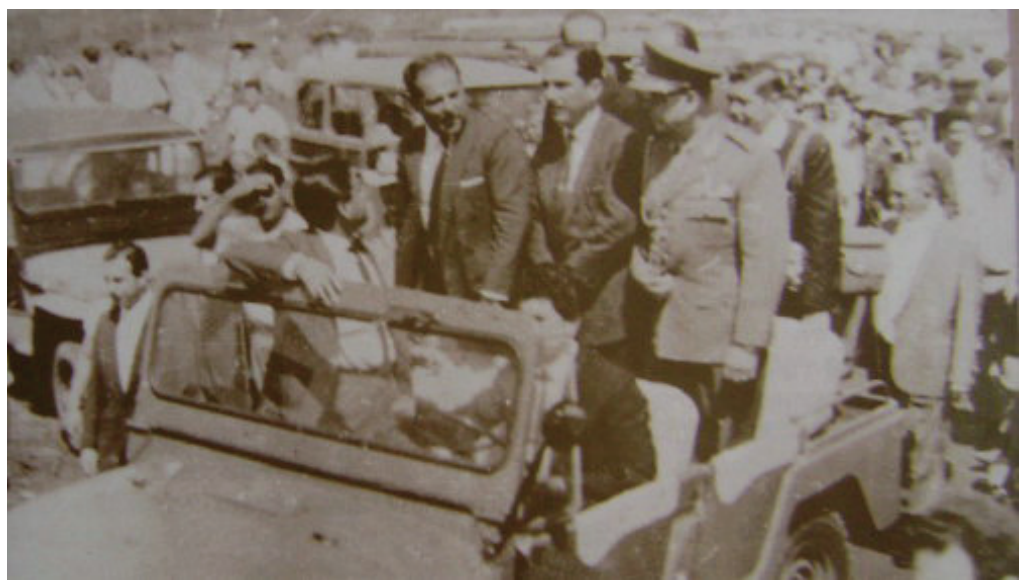

Figura 5: Presidente João Goulart, em pé, à esquerda, na Praça Presidente Vargas, em Francisco Beltrão, em 17/03/1962, para a abertura do processo de legalização das terras do Sudoeste do Paraná

Fonte: Paraná (2007, p. 127).

\section{Referências}

AMANCIO. Silvia Maria. Ontem, luta pela terra; hoje, monumento bistórico: a revolta dos posseiros no Sudoeste do Paraná em suas variadas versões. 2009. 178 f. Dissertação (Mestrado em História) - Universidade Estadual de Maringá, Maringá, 2009.

BRASIL. Senado Federal. Subsecretaria de Informações. Decreto n ${ }^{\circ} 51.431$, de 19 de março de 1962. Cria o Grupo Executivo para as Terras do Sudoeste do Paraná. Disponível em: <http://www6.senado.gov.br/legislacao/ListaPublicacoes.action?id=182398>. Acesso em: 28 fev. 2012.

DEAP- Departamento de Arquivo Público do Paraná. Jornal Gazeta do Povo, 28 set. 1957. In: Arquivo DOPS, pasta 1053, cx. 128.

GOMES, Iria Zanoni. 1957: a revolta dos posseiros. 2. ed. Curitiba: Criar, 1987.

JACOMO TRENTO, vulgo Porto Alegre, um dos líderes dos posseiros em 1957. In: PEREIRA, Niomar. Revolta dos posseiros: era chegada a hora de ir para o mato e prender os jagunços. Aqui Sudoeste, Francisco Beltrão, 23 fev. 2007.

KRÜGER, Nivaldo. Sudoeste do Paraná: história de bravura, trabalho e fé. Curitiba: Posigraf, 2004. 
LAZIER, Hermógenes. Análise histórica da posse de terra no sudoeste paranaense. Curitiba: SECE/BPP, 1986.

MARTINS, José de Souza. Os camponeses e a politica no Brasil: as lutas sociais no campo e seu lugar no processo político. 2. ed. Petrópolis: Vozes, 1983.

REGO, Rubem Murilo Leão. Tensões sociais na frente de expansão: a luta pela terra no sudoeste do Paraná - 1940-1970. In: SANTOS, José Vicente Tavares dos (Org.). Revoluções camponesas na América Latina. Campinas: Unicamp, 1985. p. 189-212.

PARANÁ. Secretaria de Estado da Cultura. 50 anos Revolta dos posseiros: resgatar o passado de lutas, para valorizar a liberdade do presente. Curitiba: SEEC, 2007.

WACHOWICZ, Ruy Cristovam. Paraná, Sudoeste: ocupação e colonização. Curitiba: Lítero-Técnica, 1985. 